\title{
Front Matter: Volume 11463
}

, "Front Matter: Volume 11463," Proc. SPIE 11463, Optical Trapping and Optical Micromanipulation XVII, 1146301 (4 September 2020); doi:

$10.1117 / 12.2576426$

SPIE. Event: SPIE Nanoscience + Engineering, 2020, Online Only 


\section{PROCEEDINGS OF SPIE}

\section{Optical Trapping and Optical Micromanipulation XVII}

Kishan Dholakia

Gabriel C. Spalding

Editors

24 August - 4 September 2020

Online Only, United States

Sponsored and Published by

SPIE 
The papers in this volume were part of the technical conference cited on the cover and title page. Papers were selected and subject to review by the editors and conference program committee. Some conference presentations may not be available for publication. Additional papers and presentation recordings may be available online in the SPIE Digital Library at SPIEDigitalLibrary.org.

The papers reflect the work and thoughts of the authors and are published herein as submitted. The publisher is not responsible for the validity of the information or for any outcomes resulting from reliance thereon.

Please use the following format to cite material from these proceedings:

Author(s), "Title of Paper," in Optical Trapping and Optical Micromanipulation XVII, edited by Kishan Dholakia, Gabriel C. Spalding, Proceedings of SPIE Vol. 11463 (SPIE, Bellingham, WA, 2020) Seven-digit Article CID Number.

ISSN: 0277-786X

ISSN: 1996-756X (electronic)

ISBN: 9781510637320

ISBN: 9781510637337 (electronic)

Published by

SPIE

P.O. Box 10, Bellingham, Washington 98227-0010 USA

Telephone +1 3606763290 (Pacific Time) · Fax +1 3606471445

SPIE.org

Copyright (c) 2020, Society of Photo-Optical Instrumentation Engineers.

Copying of material in this book for internal or personal use, or for the internal or personal use of specific clients, beyond the fair use provisions granted by the U.S. Copyright Law is authorized by SPIE subject to payment of copying fees. The Transactional Reporting Service base fee for this volume is $\$ 21.00$ per article (or portion thereof), which should be paid directly to the Copyright Clearance Center (CCC), 222 Rosewood Drive, Danvers, MA 01923. Payment may also be made electronically through CCC Online at copyright.com. Other copying for republication, resale, advertising or promotion, or any form of systematic or multiple reproduction of any material in this book is prohibited except with permission in writing from the publisher. The CCC fee code is 0277$786 \mathrm{X} / 20 / \$ 21.00$.

Printed in the United States of America by Curran Associates, Inc., under license from SPIE.

Publication of record for individual papers is online in the SPIE Digital Library.

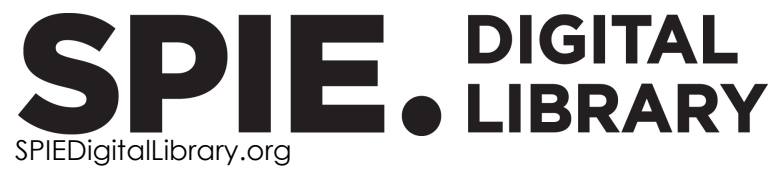

Paper Numbering: Proceedings of SPIE follow an e-First publication model. A unique citation identifier (CID) number is assigned to each article at the time of publication. Utilization of CIDs allows articles to be fully citable as soon as they are published online, and connects the same identifier to all online and print versions of the publication. SPIE uses a seven-digit CID article numbering system structured as follows:

- The first five digits correspond to the SPIE volume number.

- The last two digits indicate publication order within the volume using a Base 36 numbering system employing both numerals and letters. These two-number sets start with 00, 01, 02, 03, 04, $05,06,07,08,09,0 A, 0 B \ldots$ OZ, followed by 10-1Z, 20-2Z, etc. The CID Number appears on each page of the manuscript. 


\section{Contents}

VIRUS AND SINGLE-MOLECULE BIOPHYSICAL STUDIES AND TECHNOLOGIES

1146306 Quantification of low-affinity kinetics between cancer immunity relevant ligands and natural killer cell receptors with a self-induced back-action actuated nanopore electrophoresis

(SANE) sensor (Invited Paper) [1 1463-4]

FROM THE STATISTICAL PHYSICS OF SMALL SYSTEMS TO BIOMATERIALS I

1146309 Optical trapping of microparticles and yeast cells at ultra-low intensity by intracavity nonlinear feedback forces [11463-7]

FROM THE STATISTICAL PHYSICS OF SMALL SYSTEMS TO BIOMATERIALS II

$11463 \mathrm{OB} \quad$ Microrheology of gel electrolyte biomaterials based on deep eutectic solvents [11463-9]

11463 OC Stroboscopic detection of multi-colloidal hydrodynamics using time-multiplexed optical tweezers [11463-10]

DYNAMIC BIOPHYSICAL SYSTEMS

$114630 G$ Dynamics of Bacillus subtilis bacterium in an optical trap [1 1463-14]

NEXT-GENERATION FABRICATION TECHNOLOGIES

$114630 Q \quad$ Acoustic levitation for multimodal volumetric display (Invited Paper) [1 1463-24]

FROM THEORETICAL FOUNDATIONS TO PHOTONIC DEVICES FOR OPTICALLY INDUCED FORCES

$11463 \mathrm{OV}$ Energy, linear momentum, and spin and orbital angular momenta of circularly polarized Laguerre-Gaussian wave-packets [11463-29] 
SURFACE MANIPULATION METHODS, HYDRODYNAMICS, AND OPTICALLY BOUND MATTER

11463 OW Light-driven microrobotics and their applications for single-cell manipulation (Invited Paper) [11463-30]

11463 OX Brownian fluctuations, hydrodynamics and elasticity of a microhelix [11463-31]

SYSTEMS WITH BROKEN SYMMETRY

1146312 Polarimetry studies on birefringent materials in optical tweezers [11463-36]

1146313 Dynamics of optical forces and torques in plasmonic systems: a surface integral equation [1 1463-37]

1146315 Determination of local cell membrane slope fluctuations using the pitch rotational mode of optical tweezers [11463-39]

FROM PHOTOACOUSTICS TO PHOTOPHORESIS AND OPTO-THERMOPHORESIS

$1146316 \quad$ Photoacoustics of single aerosol droplets immobilised by counter-propagating optical tweezers [11463-40]

1146318 Migration of silver microparticles suspended in water by means of photophoresis induced with laser radiation. [11463-42]

1146319 Trapping and manipulation of a microbubble in 3D through temperature gradients [1 1463-43]

TUTORIAL ON MACHINE LEARNING IN COMPUTATIONAL IMAGING: JOINT SESSION WITH CONFERENCES 11463 AND 11469

$114631 \mathrm{~L} \quad$ On the use of deep learning for computational imaging (Keynote Paper) [1 1463-54]

PRECISION MEASUREMENT, TESTING FUNDAMENTAL PHYSICS, AND NANO-THERMODYNAMICS

$114631 \mathrm{R} \quad$ Optically induced nanoscale forces: precipitating the separation of immiscible liquids

[11463-82]

\section{POSTER SESSION}

1146320 Directed self-assembly of a bio-inspired peptide into ring microstructures using micro-bubbles induced in thermo-optical tweezers [11463-68]

iv 
$1146321 \quad$ Simulating Traumatic Brain Injury (TBI) using laser-induced shockwave under quantitative phase microscopy [11463-69]

$1146324 \quad$ Enhancement of the stiffness constant in optical tweezers by thermal effects [11463-72]

$1146325 \quad$ Understanding and optimizing laser-induced thermoelectric forces for enhanced trapping and manipulation of colloidal particles [1 1463-73]

1146326 Characterization of emission from thermo-optical tweezers during spontaneous self-assembly [1 1463-74]

1146327 Oscillation of a microbubble by means of Marangoni force [11463-75]

1146329 Generation of thermo-optical instability mediated by thermophoresis in a sessile water droplet [1 1463-77]

$114632 \mathrm{C}$ Reversal in axial symmetry of nonlinear optical trapping potential for metallic nanoparticles: generalized Lorenz-Mie theory [11463-80]

$114632 \mathrm{E} \quad$ Nonlinear optical trap: dielectrics, metals, and beyond [1 1463-84] 
Proc. of SPIE Vol. $114631146301-6$ Downloaded From: https://www.spiedigitallibrary.org/conference-proceedings-of-spie on 26 Apr 2023
Terms of Use: https://www.spiedigitallibrary.org/terms-of-use 